The next four years were busy ones for the young superintendent. He went to Germany to study the comparable organizations there and designed the new laboratories and other equipment. He gathered a small but enthusiastic staff around him, including as his chief assistant and doputy Dr. R. C. Farmer, a fellow student at Wurzburg who, with Dr. Godfrey Rotter (later director of explosives research in the establishment) and Dr. Harold Moore (later director, British Non-Ferrous Metals Research Association), among the seniors, survives him.

This period saw not only the discovery of tetryl and of the means of causing lyddite to detonate effectively in shell (it had conspicuously failed to do this in the Boer War), but also the introduction of T.N.T. into the Service and research into flashless and smokeless propellants and into steels for guns, shells and armour.

Silberrad reported to the Explosives Committee of the War Office, the chairman of which was Lord Rayleigh. In 1906, this Committee was disbanded, and in the same year Silberrad resigned, to become for the rest of his career a consulting research chemist and director of the Silberrad Research Laboratories. Had he remained in Government service, where he was such a distinguished pioneer of modern 'conventional' armaments research, there is no doubt that high office and honours could have been his.

His connexion with the armaments field was not, however, completely severed by his resignation, for in 1908 he was instrumental in providing the Admiralty with a special alloy capablo of resisting the erosion suffered by the propellers of high-speed turbine-driven warships. Because of this erosion, the future of such vessels and liners had appeared somewhat problomatical. Also, in conjunction with tho firm of Hotchkiss, he worked on erosion-resisting steel for guns. Then, in the First World War he was honorary consulting chemist to the Ministry of Munitions. An outstanding achievement of this period was the successful process for manufacturing large charges of lyddite in iron instead of earthonwaro vessels. This enabled an improved synthesis, requiring a higher temperature than was practicable with the original method, to be used. He also turned his attention once more to flashless propellants and developed one for use in large howitzers.

Silberrad was a brilliant experimenter, and among other achievements of his fertile brain were a new chlorinating agent; a method of manufacturing isoprene; a new means of blasting petroloum wells; and the production of dyestuffs from T.N.T. residues.

I have very pleasant memories of a visit paid to Dryads' Hall and its adjoining laboratory in 1953, when I was collecting material for an article in connoxion with the golden jubilee of Silberrad's old establishment, which by then had becomo tho Armament Research Establishment of the Ministry of Supply. I was most hospitably and kindly receivod by Dr. and Mrs. Silberrad and given access to many old photographs and exhibits, over the assembly of which mueh trouble had been taken. This first, and unfortunately tho last, personal contact with Dr. Silberrad left an impression of a man of intense mental vigour, drive and alertness, in spite of his seventy-five yoars and the fact that at the timo he had not fully recovored from an attack of thrombosis.

Mrs. Silberrad survives her husband, with the only son of the marriage.

J. S. GRew

\section{Dr. Eric Ellenbogen}

Dr. EILENBogen was born in Vienna in 1921 and ernigrated to the United States in 1940. Ho received his B.S. degree in chemistry from Indiana University in 1943. During 1943-46 he served with the Unitod States Army in India and Burma. After his discharge, he studied at the Brooklyn Polytechnic Institute, working on inorganic plastics. In 1946 he entered Harvard University, roceived his M.A. in 1947 and his Ph.D. in 1949 under the guidance of Dr. J. L. Oncley. His dissertation dealt with the determination of the physical-chemical properties of insulin. From 1947 until 1949 he was a teaching assistant in the University Laboratory of Physical Chemistry Related to Medicine and Public Health, Harvard University. He was awarded a U.S. Public Health Service Postdoctorate Research Fellowship in 1949, which he held until $195 \mathrm{I}$ in the Department of Biochemistry, Columbia University College of Physicians and Surgeons, under the sponsorship of the late Dr. E. Brand, studying the properties of tri- and tetrapeptides of specific steric configurations. In $1951 \mathrm{he}$ was appointed research associate in the Department of Biochemistry and Nutrition, Graduate School of Public Health, University of Pittsburgh, and was promoted to assistant professor in 1952 and associate professor in 1957.

In 1959 he took leave from his post at the University of Pittsburgh to travel to the Weizmann Institute at Rehovot, Israel, to study with Prof. E. Katchalski, doing research on physical properties of cortain polypeptides as models for certain proteins of biological significance. On the way back from the Weizmann Institute to the United States, Dr. Ellenbogen died of a coronary occlusion in Marseilles on May 29, 1960. Ho is survived by his wife Lois and two children.

$\mathrm{H}_{\theta}$ belonged to several American and British learned societies. His contributions to biochemistry include the study of the physical-chemical behaviour of insulin in dilute solution, the physical chemistry of specific polypeptides, the isolation of a non-insulin hypoglycæmic factor from pancreas, and the physicalchemical characterization of cardiac myosin.

ROBERT E. OLsON

\section{Prof. Eduard Reichenow}

Eduard Rfichenow, the eminent German protozoologist, died on March 23 in his seventy-seventh year. He was born in Berlin and was the product of a race versed in the natural sciences: his father, Anton, was a well-known ornithologist; his grandfather, Cabanis, a zoologist of note. He himself married Lilly Mudrow, of international fame in the field of malariology and who collaborated with him in his later work on avian malaria; her death three years ago cast a cloud over his life from which he was scarcely able to emerge.

Reichenow was oducated at Schiller-Realgimnasium in Charlottenburg ; later he entered the Universities of Heidelberg, Berlin and Munich, where he graduated in natural seience.

He was associated with the Institute of Tropical Medicine, Hamburg, for most of his academic years, first as a student, for many years as director of its Department of Protozoology, and finally as its president. He travelled extensively in the pursuit of his work, and some of these journoys produced results of great scientifie value the discovery of malaria parasites in gorillas in the Cameroons, the 